portrays the king getting up in the morning and finally going to bed, having spent the day in dealing with the necessary duties of his office. There are ten full-page illustrations, including a bead crown, drums, wine gourds, pire bowls, etc. The whole is well put together and gives a good picture of native life from the point of view of a king.

\section{The Trans-Atlantic Telephone Cable}

A JorNT meeting of the Institution of Electrical Engineers, the American Institute of Electrical Engineers and the Engineering Institute of Canada was held on January 24, during which the lecture theatres of these three bodies in London, New York and Montreal were connected together by the transAtlantic telephone cable, which was opened for public service last September. At the beginning of the proceedings, the presidents of the American and Canadian bodies appointed Sir Gordon Radley, president of the Institution of Electrical Engineers, to act as chairman of the joint meeting. Thereafter, for about an hour, the authors of each of twelve papers spoke in turn over the cable, giving a brief account of the planning, design, construction and laying of the various sections of the cable. At the end of the symposium the clarity of transmission over the cable was demonstrated when identical recordings of music were played in London and New York. Switching from one source to the other gave an immediate comparison of quality between the locally produced music and its counterpart from across the Atlantic. Without the indicator provided in the lecture theatre in London, it would have required a very sensitive musical ear to determine the source of the music.

\section{Nuclear Energy and the Mellon Institute}

THE entry of the Mellon Institute into the field of the peaceful applications of nuclear energy is announced in a seven-page booklet recently issued by the Institute. A Department of Radiation Research is to be established, under the directorship of Dr. Robert H. Schuler, who was formerly a member of the staff of the Brookhaven National Laboratory. The facilities of the new Department are to include a 3-million volt Van dè Graaff accelerator, laboratories for radiochemical and allied work, laboratories for general work, a radiation library, offices, and equipment for using radioactive cobalt and other radiation sources. The Department of Radiation Research will be the sixth department established by the Institute to aid the numerous comprehensive research programmes sponsored by industrial concerns or associations.

\section{Spectral Types of Southern Stars}

IN 1949 it was decided to re-classify the objectiveprism spectra taken by the late W. B. Rimmer, and partly described in Mem. Commonwealth Solar Obs., No. $2 ; 1930$. This description is in accordance with the newer system developed by W. W. Morgan and his associates, an account of which appeared under the title "An Atlas of Stellar Spectra" (Univ. of Chicago Press, 1943). Dr. S. C. B. Gascoigne supervised Miss M. L. Woods in the conduct of this work, which was completed in 1951 but remained unpublished until Dr. W. Buscombe was able to take the responsibility of editing the date for publication (Memoirs of the Commonwealth Observatory, Mount Stromlo, Canberra; Memoir No. 12 (3, No. 2).
Spectral Types of Bright Southern Stars. By Mary Lee Woods ; May 1955). The Memoir deals with 520 bright stars and includes all the stars for which Rimmer's spectra are sufficiently clear, with the exception of a few composite spectra, and in addition to the data contained in nine pages of tabular matter, three pages are devoted to an introduction, procedure, notes on different types, absolute magnitudes, the catalogue, and acknowledgments.

\section{Venezuelan Institute for Neurology and Brain Research}

THE first (pilot) section of the Venezuelan Institute for Neurology and Brain Research (see Nature, 176, 1049 ; 1955) has now been completed and the Institute has issued an illustrated brochure which is available on application to the director, Dr. H. Fernandez-Moran, Instituto Venezolano de Neurologia e Investigaciones Cerebrales, Caracas, Venezuela. The brochure gives a plan and photographs of the Institute and indicates the work of the various departments. The use of the ultramicrotome and the production of diamond knives is described and a section deals with the application of nuclear magnetic resonance spectrometry to cell studies. Next March the Institute will be holding an international symposium on "The Fine Structure of the Nervous System" under the auspices of the International Society for Cell Biology.

\section{Scientific Institutions in Latin America}

A SECOND volume of "Scientific Institutions and Scientists in Latin America", dealing with Colombia, issued by the United Nations Educational, Scientific and Cultural Organization (Centro de Cooporacion Cientifica para America Latina, Montevideo. Instituciones Cientificas y Cientificos Latinoamericanos. Colombia. (20 Volumen.) Pp. ii +176. Montevideo, 1956), contains information, revised and brought up to date, on institutions and scientists, contained in Vol. 1, issued in 1949, as well as on some not formerly included. The arrangement is alphabetical for both institutions and scientists, and there is in addition a subject-index.

\section{Scientific Research at the British Museum (Natural History)}

THE British Museum (Natural History) has such an attraction for the general public that its main function as an institution for scientific research tends to be hidden. For this reason the production of a booklet describing some of the research which has been and is still being done at the Museum will be welcomed by many visitors as well as all natural history scholars ("Scientific Research at the Natural History Museum". Pp. vi +46 . London: British Museum (Natural History), 1956. 2s. 6d.). The booklet describes the way in which the main research activities in various departments are organized, as well as specific investigations by individual sections or members of each department. The booklet is well written and well illustrated and should prove a valuable addition to the publications of the Museum. If a reprint is made, the cover of the journal might bear a closer relation to its contents than one which appears to be more appropriate for publications of the Science Museum.

\section{Sarawak Museum, Borneo}

During the past few years there has been news from time to time of the great vitality of the Sarawak 